\title{
Possible Influence of Dopaminergic Receptor in Maintenance of Thyroid Hormone Homeostasis: A Study in Adult Rat Brain
}

\author{
Samita Kundu ${ }^{\mathrm{a}}$, Sumedha Roy ${ }^{\mathrm{b}}$, Angshuman Biswas ${ }^{\mathrm{b}}$, Jhuma De ${ }^{\mathrm{b}}$, \\ Mitali Pramanik ${ }^{\mathrm{b}}$, Arun K. Ray ${ }^{\mathrm{b}, \mathrm{c}}$
}

\begin{abstract}
Background: The role of thyroid hormone (TH) disbalance in genesis of psychological disturbances in the adult humans is well known. A phenomenon of 'central thyroid hormone homeostasis' characterized by increased synaptosomal T3 content, deiodinase type II (DII) activity and cAMP level, is known to exist during peripheral hypothyroidism. This phenomenon tries to counteract the adverse psychobehavioural manifestations commonly associated with TH deficiency. A close physiological association between sympathetic nervous system activity and TH is well known. Dopamine, a predominant catecholamine neurotransmitter in the mammalian brain, controls a variety of functions including locomotion, cognition, emotion and also affects neuroendocrine secretion. In the present study relationship between $\mathrm{TH}$ and dopamine has been presumed to be involved in the maintenance of "central thyroid hormone homeostasis' in adult rat.
\end{abstract}

Methods: We injected specific dopaminergic receptor agonists and antagonists along with an antithyroid drug (PTU) to find out any effect on 'central homeostasis' in adult rat.

Results: The dopaminergic agonist did not alter the onset of 'central homeostasis', but prolonged its duration by maintaining the control level of cerebral T3. Injection of the antagonist did not cause any perturbation. These results have been supported by parallel changes in cerebrocortical DII activity and cAMP.

Conclusions: In the present experiment a striking feature is that a

Manuscript accepted for publication June 20, 2012

${ }^{\mathrm{a}}$ Department of Zoology, Vivekananda College, 269 Diamond Harbour Road, Calcutta 700063, India

${ }^{\mathrm{b}}$ Division of Molecular Medicine, Bose Institute, P1/12 CIT Scheme VIIM, Calcutta 700054, India

${ }^{\mathrm{c} C o r r e s p o n d i n g ~ a u t h o r: ~ A r u n ~ K ~ R a y, ~ D i v i s i o n ~ o f ~ M o l e c u l a r ~ M e d i c i n e, ~}$ Bose Institute, P 1/12, CIT Scheme, VII M, Calcutta 700054, India.

Email: akray@bic.boseinst.ernet.in

doi:10.4021/jem101w
$\mathrm{D}_{2}$-receptor mediated inhibition of cAMP accumulation has been reversed to $D_{1}$-receptor mediated stimulation of cAMP accumulation probably by the effect of "central thyroid hormone homeostasis'. This effect of $\mathrm{D}_{2}$-agonist can be therapeutically utilized for prolonging the duration of homeostasis.

Keywords: Thyroid hormone; Central homeostasis; Dopaminergic receptor; Deiodinase II; cAMP

\section{Introduction}

A relationship between thyroid hormone (TH) and catecholamines exist in the CNS. The plausibility of such interactions is strengthened by their common origin in the amino acid tyrosine [1]. TH imbalance has been reported to influence the activity of the primary dopamine synthesizing enzyme tyrosine hydroxylase [2]. Similarities between the symptomatology of thyroid deficiency and of certain psychiatric illnesses, particularly 'endogenous' depressions are well known [3]. TH interaction with the aminergic system may have relevance for the understanding of the mood modulating effects of THs in the clinical setting and thus may enhance the understanding of the pathophysiology and treatment of mood disorders [4]. Moreover psychiatric drugs have a marked influence on peripheral TH levels, suggesting involvement of an effect on central TH metabolism. Infact, animal studies have shown that antidepressants affect deiodinase activities and T3/T4 concentrations in rat brain [5]. Nothing is known about the effect of dopamine (DA) in maintenance of cerebral TH levels effecting to 'central thyroid hormone homeostasis' during peripheral hypothyroidism [6].

The present work is directed towards understanding the influence of drugs acting on the dopaminergic receptors, on the mechanism of 'central thyroid hormone homeostasis'. Haloperidol is an anti-psychotic drug regarded as a dopaminergic receptor (primarily $\mathrm{D}_{2}$ ) antagonist that blocks impulse transmission in dopaminergic neurons. Bromocryptine, an antiparkinsonian drug, is a potent agonist for $\mathrm{D}_{2}$ receptor and also a partial agonist or antagonist at $\mathrm{D}_{1}$ receptor. 


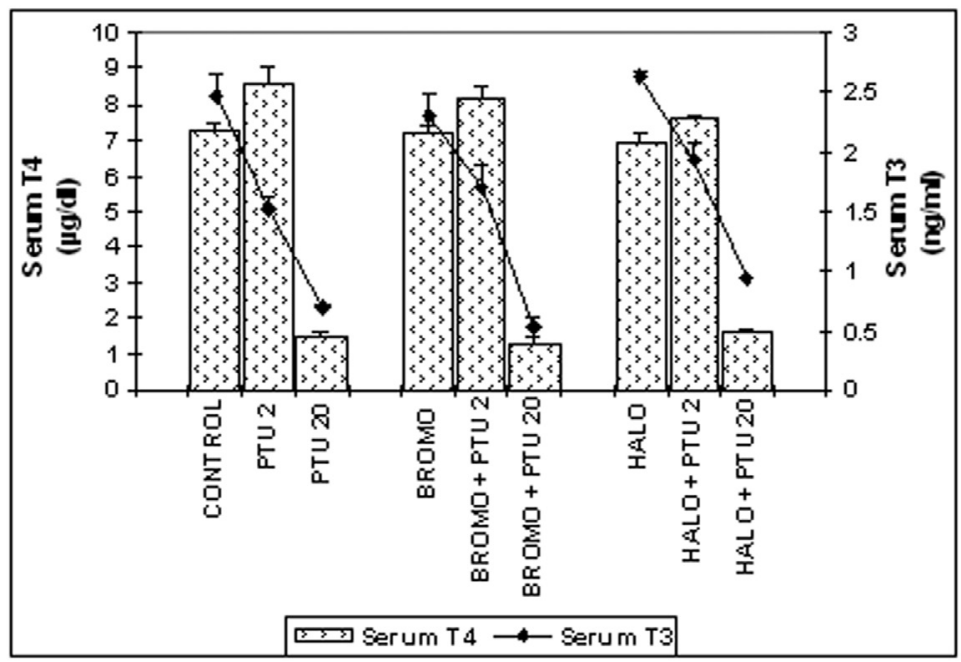

Figure 1. Serum total T4 $(\mu \mathrm{g} / \mathrm{dL})$ and T3 $(\mathrm{ng} / \mathrm{mL})$ concentrations. Daily intra-peritoneal injections of different doses of Bromocriptine (BROMO, dopaminergic agonist) and Haloperidol (HALO, antagonist) were given to adult male Sprague Dawley rats either singly or in combination with PTU (2 mg/100g b.w.) for the first (Day ' 0 ' and ' 1 ') and last (Day '18' and '19') two consecutive days preceding the onset (Day '2') and termination (Day '20'), of 'central thyroid hormone homeostasis'. Parallel control animals were injected with equal volume of vehicle. Blood samples for T4/T3 ELISA were collected from the retro-orbital sinus on the day of onset (Day '2') and termination (Day '20') of 'central homeostasis' and $24 \mathrm{~h}$ after the last injections. Data are presented as Mean \pm SEM of $12-15$ individuals in each group, pooled from three sets of experiments. The vertical lines denote standard error.

\section{Materials and Methods}

\section{Animals and treatment}

Adult male albino Sprague Dawley rats weighing 150 - 160 $\mathrm{g}$ were maintained in a temperature-controlled room $(24 \pm 1$ ${ }^{\circ} \mathrm{C}$ ) with 12 hour light-dark cycle. They were fed ad libitum with standard rat diet and given free access to drinking water.

Rats were injected intraperitoneally with the dopaminergic receptor agonist bromocryptine (BROMO, 2-Bromo- $\alpha$-ergocryptine methanesulfonate salt, Sigma Chemical Co., USA) at a dose of $5 \mathrm{mg} / \mathrm{kg}$ b.w. either singly or in combination with PTU (6n-propyl-2-thiouracil, Sigma Chemical Co., USA) at a dose of $2 \mathrm{mg} / 100 \mathrm{~g} \mathrm{~b}$.w. for two consecutive days (Days ' 0 ' and ' 1 ') and sacrificed on Day ' 2 ' or the day of onset of 'central thyroid hormone homeostasis' [6]. Similarly they were injected with dopaminergic receptor antagonist haloperidol (HALO, Sigma Chemical Co., USA) at a dose of $0.1 \mathrm{mg} / \mathrm{kg}$ b.w. either singly or along with PTU for two consecutive days and sacrificed on Day ' 2 '. BROMO and HALO were also administered on Days ' 18 ' and ' 19 ' with PTU which was being given daily from Day ' 0 ' and sacrificed on Day '20' or day of termination of 'central thyroid hormone homeostasis' [6]. Control animals were given injections of vehicle (alkalinised normal saline) and were kept in parallel with the treated groups. The doses of BROMO and HALO were optimized from previous studies on rats. In experiments where simultaneous injections were given, PTU was injected after $30 \mathrm{~min}$ of pretreatment with single injections of these drugs. Each group consisted of a total of 12 - 15 animals pooled from three experimental repeats.

The experiment was approved by our Institutional ethical committee and performed according to the guidelines for care and use of experimental animals of Govt. of India.

\section{Preparation of synaptosome}

Synaptosomes from the cerebral cortex were prepared according to the method of Sarkar and Ray [7]. Briefly, a 10\% cerebrocortical homogenate in $0.32 \mathrm{M}$ sucrose was centrifuged at 2000 x $g$ (Heraues Sepatech, Biofuge 28RS, Germany) at $4{ }^{\circ} \mathrm{C}$ for $5 \mathrm{~min}$. The supernatant was cautiously layered over 1.2 M sucrose and centrifuged at 50,000 x $g$ at $4{ }^{\circ} \mathrm{C}$ for $50 \mathrm{~min}$ in ultracentrifuge (Beckman-L7, USA). The fraction between $1.2 \mathrm{M}$ and $0.32 \mathrm{M}$ was carefully collected, diluted in $1: 1.5$ ratio with ice-cold double distilled water, again layered over $0.8 \mathrm{M}$ sucrose and centrifuged at 50,000 x $\mathrm{g}$ for $30 \mathrm{~min}$ at $4{ }^{\circ} \mathrm{C}$. The synaptosomal pellet obtained was washed, suspended in $0.32 \mathrm{M}$ sucrose and preserved in $-80^{\circ} \mathrm{C}$. The purity of synaptosomes was checked as described by Sarkar and Ray [7]. The synaptosomes were ruptured hypo-osmotically with ice-cold bidistilled water for hormone assay.

A small part of the homogenate was directly centrifuged at $15,000 \times \mathrm{g}$ at $4{ }^{\circ} \mathrm{C}$ for $20 \mathrm{~min}$. The pellet was discarded and the supernatant (post-mitochondrial fraction) was taken for estimation of deiodinase type II (DII) activity and cAMP content. 


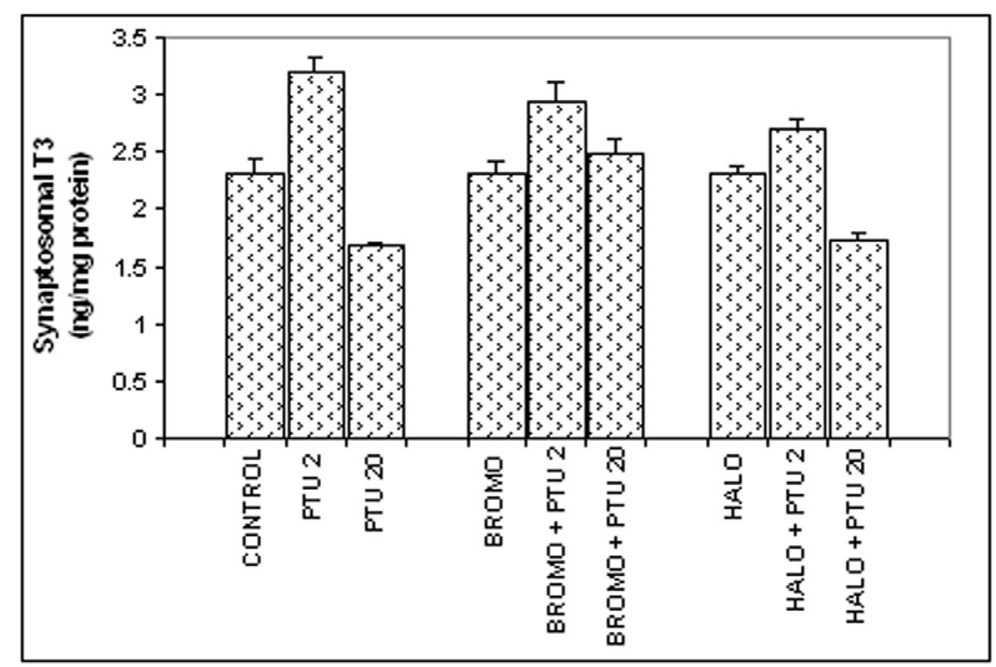

Figure 2. Synaptosomal total T3 content (ng/mg synaptosomal protein). Daily intra-peritoneal injections of different doses of Bromocriptine (BROMO, dopaminergic agonist) and Haloperidol (HALO, antagonist) were given to adult male Sprague Dawley rats either singly or in combination with PTU (2 mg/100g b.w.) for the first (Day '0' and ' 1 ') and last (Day '18' and '19') two consecutive days preceding the onset (Day '2') and termination (Day '20'), respectively, of 'central thyroid hormone homeostasis'. Parallel control animals were injected with equal volume of vehicle. Animals were sacrificed and cerebral cortex collected on Day ' 2 ' and Day '20' (after $24 \mathrm{~h}$ of the last injections) for preparation of synaptosome for T3 ELISA. Data are presented as Mean \pm SEM of 12 - 15 individuals in each group, pooled from three sets of experiments. The vertical lines denote standard error.

\section{ELISA of thyroid hormones}

ELISA of total T4 and T3 from serum and synaptosomes were made through respective competitive enzyme immunoassay kits (Monobind Inc., CA, USA) as described earlier $[6,8]$. The absorbance was read at $450 \mathrm{~nm}$ (reference wavelength of $620-630 \mathrm{~nm}$ ) in an ELISA reader (Multiskan EX, Thermo Labsystems, Finland). The sensitivities of the kits for total T4 and T3 were $0.4 \mu \mathrm{g} / \mathrm{dL}$ and $0.04 \mathrm{ng} / \mathrm{mL}$ respectively.

\section{Assay of iodothyronine 5'-deiodinase type II}

The 5'-deiodinase type II (DII) activity has been measured according to the method of Kodding et al. [9] with slight modifications [8], using a substrate solution of $0.1 \mathrm{M}$ TrisHCl buffer (pH 7.4), 3 mM EDTA, 150 mM dithioerythritol, $0.4 \mu \mathrm{M} \mathrm{T} 4$ and $100-150 \mu \mathrm{g}$ brain tissue protein. The T3 formed under such conditions after incubation were estimated by ELISA.

\section{Determination of cAMP content}

The cyclic AMP (cAMP) content has been assayed by competitive enzyme immunoassay, as described before [8] using a cAMP EIA kit from Cayman Chemical Co., USA. The plates were read at a wavelength between 405 and $420 \mathrm{~nm}$ in ELISA reader. The assay had $100 \%$ specificity for cAMP with a detection limit of $0.07 \mathrm{pmol} / \mathrm{mL}$.

\section{Protein estimation}

Protein content of the samples was determined by the method of Bradford [10] using BSA (Sigma Chemical Company, USA) as standard.

\section{Statistical analysis}

Data are expressed as Mean \pm SEM of the number of experiments indicated. Statistical significance was analyzed by one-way ANOVA followed by Newmann-Keuls post hoc test for comparison between multiple groups. The significance level was determined at $\mathrm{P}<0.05$.

\section{Results}

\section{Serum total T4 and T3 (Fig. 1)}

Bromocryptine (BROMO, dopaminergic agonist) when injected singly for two days had a serum total T4 level of $7.18 \pm$ $0.18 \mu \mathrm{g} / \mathrm{dL}$ identical to a control of $7.25 \pm 0.19 \mu \mathrm{g} / \mathrm{dL}$ on Day ' 2 '. It showed a significant rise to $8.19 \pm 0.34 \mu \mathrm{g} / \mathrm{dL}(\mathrm{P}<0.05)$ when PTU was also injected. Single injections of Haloperidol (HALO, antagonist) maintained the serum T4 value at 6.963 $\pm 0.22 \mu \mathrm{g} / \mathrm{dL}$ statistically similar to the control. Combined administration of PTU with HALO for two days also showed the T4 level of $7.624 \pm 0.08 \mu \mathrm{g} / \mathrm{dL}$ identical to control, but significantly greater $(\mathrm{P}<0.05)$ than only HALO group. These 


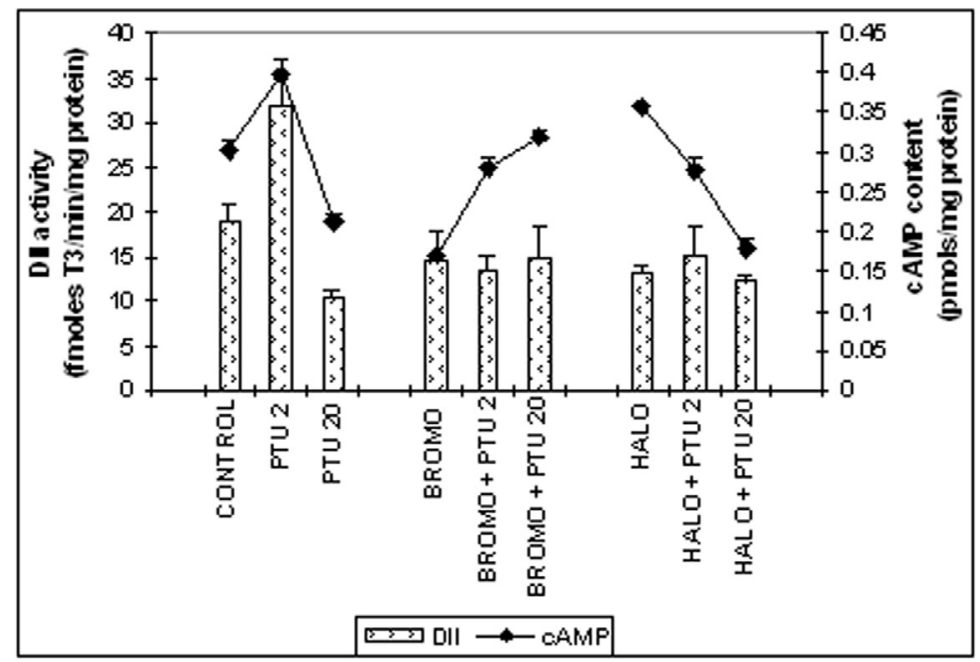

Figure 3. Cerebro-cortical 3, 5, 3'-iodothyronine deiodinase type II (DII) activity (fmoles T3 formed/min/mg protein) and cAMP content (pmoles/mg protein). Daily intra-peritoneal injections of different doses of Bromocriptine (BROMO, dopaminergic agonist) and Haloperidol (HALO, antagonist) were given to adult male Sprague Dawley rats either singly or in combination with PTU (2 mg/100g b.w.) for the first (Day ' 0 ' and ' 1 ') and last (Day '18' and '19') two consecutive days preceding the onset (Day '2') and termination (Day '20'), respectively, of 'central thyroid hormone homeostasis'. Parallel control animals were injected with equal volume of vehicle. Animals were sacrificed and cerebral cortex collected on Day '2' and Day '20' (after 24 h of the last injections) for determination of DII activity. Data are presented as Mean \pm SEM of $12-15$ individual animals in each group, pooled from three sets of experiments. The vertical line denotes standard error.

values were significantly less than the only PTU-treated group $(8.58 \pm 0.21 \mu \mathrm{g} / \mathrm{dL} ; \mathrm{P}<0.01)$ on this day. Injections of PTU for twenty consecutive days along with either of BROMO and HALO on the last two days (18th and 19th day) resulted in significantly lower serum T4 level of $1.266 \pm 0.17$ and $1.639 \pm$ $0.05 \mu \mathrm{g} / \mathrm{dL}$ respectively on Day '20' compared to only BROMO or HALO-treated animals $(\mathrm{P}<0.001)$, but were identical to only PTU-treated rats at $1.44 \pm 0.12 \mu \mathrm{g} / \mathrm{dL}$.

Injections of BROMO and HALO for two successive days had a serum total T3 level of $2.303 \pm 0.18$ and $2.635 \pm$ $0.04 \mathrm{ng} / \mathrm{mL}$ respectively, which were identical to the control level of $2.469 \pm 0.21 \mathrm{ng} / \mathrm{mL}$ on Day '2' and significantly higher than the T3 level of only PTU-treated animals (1.514 $\pm 0.08, \mathrm{P}<0.05)$. However, PTU injections given to rats also treated before with BROMO or HALO declined the T3 content to $1.707 \pm 0.17 \mathrm{ng} / \mathrm{mL}(\mathrm{P}<0.05)$ and $1.947 \pm 0.14 \mathrm{ng} /$ $\mathrm{mL}(\mathrm{P}<0.01)$ respectively, similar to the only PTU-treated group. When PTU was injected for twenty days along with either BROMO and HALO on the last two days (18th and 19th day), there was a significantly low serum total T3 level of $0.525 \pm 0.08$ and $0.925 \pm 0.03 \mathrm{ng} / \mathrm{mL}$ respectively, compared to only BROMO and HALO-treatment groups (2.303 \pm 0.18 and $2.635 \pm 0.04 \mathrm{ng} / \mathrm{mL}$ respectively, $\mathrm{P}<0.001)$, but similar to the value of PTU treatment alone on Day '20' $(0.691 \pm 0.08 \mathrm{ng} / \mathrm{mL})$.

\section{Synaptosomal total T3 content (Fig. 2)}

There was no change in the synaptosomal total T3 content in comparison to the control value of $2.321 \pm 0.12 \mathrm{ng} / \mathrm{mg}$ protein, when BROMO and HALO were injected singly for $(2.306 \pm 0.118$ and $2.315 \pm 0.083 \mathrm{ng} / \mathrm{mg}$ protein respectively). However, PTU injections given to the BROMO-treated rats showed a comparatively higher synaptosomal T3 content $(2.943 \pm 0.173 \mathrm{ng} / \mathrm{mg}$ protein $)$ than control and only BROMO rats $(\mathrm{P}<0.05)$, but identical to rats treated only with PTU for two days (3.169 \pm 0.11$)$. Simultaneous injections of HALO and PTU for two days (Days ' 0 ' and ' 1 ') also increased the synaptosomal T3 level to $2.713 \pm 0.07 \mathrm{ng} / \mathrm{mg}$ protein $(\mathrm{P}<0.05)$ compared to control, but less than only PTU group $(\mathrm{p}<0.05)$. Injection of BROMO on the last two days preceding Day '20' to rats already injected with PTU from ' 0 ' day maintained the synaptosomal total T3 content at $2.495 \pm 0.127 \mathrm{ng} / \mathrm{mg}$ protein, similar to control and only BROMO-treated rats. But HALO injection on the last two days to PTU-injected animals resulted in a brain T3 level of $1.746 \pm 0.047 \mathrm{ng} / \mathrm{mg}$ protein similar to PTU-treated rats $(1.699 \pm 0.03 \mathrm{ng} / \mathrm{mg}$ protein) and significantly lower than control and only HALO-treated group $(2.315 \pm 0.083 \mathrm{ng} / \mathrm{mg}$ protein, $\mathrm{P}<0.01)$.

\section{Cerebrocortical DII activity (Fig. 3)}

The DII activity was $14.5 \pm 3.2$ fmoles $\mathrm{T} 3 / \mathrm{min} / \mathrm{mg}$ protein on Day '2' for rats given injections of BROMO daily for two days (Days '0' and ' 1 '), similar to an activity of $18.9 \pm 3.1$ fmoles $\mathrm{T} 3 / \mathrm{min} / \mathrm{mg}$ protein of control rats. This activity remained at $13.5 \pm 1.6 \mathrm{fmoles} \mathrm{T} 3 / \mathrm{min} / \mathrm{mg}$ protein when BRO- 
MO was injected simultaneously with PTU for two days and was significantly less than the activity of only PTU-treated animals for two days $(31.9 \pm 2.5$ fmoles $\mathrm{T} 3 / \mathrm{min} / \mathrm{mg}$ protein, $\mathrm{P}<0.01$ ). Rats injected with HALO only or along with PTU for two days showed DII activities of $13.5 \pm 0.9$ and $15.1 \pm$ $3.2 \mathrm{fmoles} \mathrm{T} 3 / \mathrm{min} / \mathrm{mg}$ protein respectively, similar to control. The DII activity remained at $15.0 \pm 3.4$ fmoles T3 $/ \mathrm{min} /$ mg protein when PTU was treated for twenty days and preceded by pretreatment with BROMO on the 18th and 19th day and also remained statistically unchanged in comparison to only PTU-treated rats on Day '20' (10.4 \pm 0.7 fmoles T3/ $\mathrm{min} / \mathrm{mg}$ protein). Similarly, HALO treatment on the last two days preceding Day '20' along with PTU did not change the DII activity that remained at $12.1 \pm 0.8$ fmoles $\mathrm{T} 3 / \mathrm{min} / \mathrm{mg}$ protein.

\section{Cerebrocortical cAMP content (Fig. 3)}

When BROMO was injected singly for two days (Days ' 0 ' and ' 1 '), a brain cAMP content of $0.171 \pm 0.028$ pmoles/ mg protein was noted on Day ' 2 ' that was significantly less than the control value of $0.301 \pm 0.011 \mathrm{pmoles} / \mathrm{mg}$ protein $(\mathrm{P}<0.001)$. A value of $0.281 \pm 0.012$ pmoles $/ \mathrm{mg}$ protein, identical to control level was found when PTU was also injected, but showed significantly less than only PTU-treated rats $(0.399 \pm 0.011, P<0.05)$. Single injection of HALO enhanced the cAMP value to $0.356 \pm 0.003 \mathrm{pmoles} / \mathrm{mg}$ protein in comparison to control $(\mathrm{P}<0.05)$. However, administration of PTU plus HALO for two days (Days ' 0 ' and ' 1 ') declined the cAMP level to $0.276 \pm 0.017$ pmoles $/ \mathrm{mg}$ protein, identical to control. BROMO injection on the 18th and 19th days to PTU-pretreated animals from ' 0 ' day resulted in significant increase in cAMP content to $0.317 \pm 0.010$ pmoles $/ \mathrm{mg}$ protein $(\mathrm{P}<0.001)$ on Day '20' compared to control. But HALO administration on the last two days to PTU-injected animals resulted in a cAMP level of $0.178 \pm 0.015$ pmoles/ $\mathrm{mg}$ protein that was significantly lower than control $(\mathrm{P}<$ 0.001 ), but statistically similar to only PTU-treated rats for twenty days $(0.211 \pm 0.009 \mathrm{pmoles} / \mathrm{mg}$ protein $)$.

\section{Discussion}

Dopamine (DA) is a predominant catecholamine neurotransmitter in the mammalian brain that controls a variety of functions including locomotion, cognition, emotion and affects neuroendocrine functions. Low or high concentration of DA is associated with Parkinson's disease or schizophrenia. Maintenance of DA concentration is necessary to avoid neurobehavioural abnormalities. In the CNS, DA receptors are widely expressed and DA is also known to be co-released with norepinephrine from noradrenergic neurons in the cerebral cortex [11]. The diverse physiological actions of DA are mediated by at least five distinct G-protein coupled re- ceptor (GPCR) subtypes. Two $\mathrm{D}_{1}$-like receptor subtypes $\left(\mathrm{D}_{1}\right.$ and $\mathrm{D}_{5}$ ) are coupled to stimulatory-G protein activating adenylyl cyclase to enhance cAMP levels. The other receptor subtypes belong to the $\mathrm{D}_{2}$-like subfamily $\left(\mathrm{D}_{2}, \mathrm{D}_{3}\right.$ and $\left.\mathrm{D}_{4}\right)$ and belong to the class of GPCRs that inhibit adenylyl cyclase and activate $\mathrm{K}^{+}$channels $[12,13]$. The relationship between thyroid hormones and dopaminergic system is not new. The presence of $\mathrm{TH}$ nuclear receptor in dopaminergic neurons has been correlated with a morphological effect of L-T3 in this neuronal population and suggests that some effects of $\mathrm{T} 3$ on the maturation of DA neurons may result from a direct effect of this hormone through an interaction with its specific nuclear receptors [14]. Neonatal hypothyroidism is related to decrease in the number of striatal $\mathrm{D}_{1}$ - and $\mathrm{D}_{2}$-receptors and impairment of $\mathrm{D}_{1}$ receptor-coupled second messenger activity. These may play a role in the derangement of those neurobehavioural patterns where dopaminergic regulation is involved [15].

In our study, the alterations in serum total $\mathrm{T} 4$ and $\mathrm{T} 3$ levels observed on Day ' 2 ' and Day '20' of PTU treatment were typical of peripheral hypothyroidism involving hypothalamo-pituitary-thyroid axis $[6,16]$. There were no changes in serum total $\mathrm{T} 4$ and $\mathrm{T} 3$ concentrations when the dopaminergic agonist, bromocryptine (BROMO), and antagonist, haloperidol (HALO), were treated to animals, either alone or in combination with PTU, on Day '2' and Day '20'. Although there are reports that DA exert inhibitory effect on TSH secretion and T4 release $[17,18]$, the unchanged serum concentrations observed in the present case might be due to the very short duration (only two days) of treatment with these two drugs.

The cerebrocortical synaptosomal total T3 content was raised on Day ' 2 ' and declined on Day ' 20 ' of peripheral hypothyroidism induced by PTU treatment. In fact, these two days have been regarded as the respective days of onset and termination of 'central thyroid hormone homeostasis' [6]. $\mathrm{BROMO}$, primarily a $\mathrm{D}_{2}$-receptor agonist, injected in combination with PTU, showed similar effect like that of PTU only, that is, there was a rise in T3 level on Day ' 2 '. The $\mathrm{D}_{2}$-receptor antagonist HALO, on the other hand, did not significantly raise the brain $\mathrm{T} 3$. While $\mathrm{BROMO}$ is a $\mathrm{D}_{2}$-agonist involved in inhibition of cAMP accumulation, and HALO being the antagonist at the same receptor, it can be speculated here that the effect is typical of initiation of 'central thyroid hormone homeostasis' using only PTU [6]. It must be stressed here that BROMO plus PTU (unlike HALO plus PTU) maintained the synaptosomal T3 at the control value on Day ' 20 ', thereby preventing the termination of the homeostatic mechanism. The reason for maintenance can be attributed to an unchanged level of DII activity as explained below.

Type II 5'-iodothyronine deiodinase (DII) influences the first step in thyroid hormone action in brain by catalyzing the monodeiodination of $\mathrm{T} 4$ to the bioactive $\mathrm{T} 3$ and the activity 
of this enzyme is increased in hypothyroidism [19]. Thus, increase in DII activity on the 2nd day of PTU treatment (Day ' 2 ') pointed to an adaptive increase in response to PTU-induced peripheral hypothyroidism to maintain the neural T3 content [8]. Again, the fall in DII activity after twenty days of continuous PTU injections (Day '20') provide the reason for lower synaptosomal T3 content and disruption of 'central thyroid hormone homeostasis' in our experimental system [8]. The DII activity after treatment with the BROMO was found to be at the control level both during the onset (Day '2') and termination (Day '20') of 'central thyroid hormone homeostasis'. But the higher synaptosomal T3 observed on Day ' 2 ' cannot be accounted by the unchanged DII activity and has been discussed later. However, an identical synaptosomal T3 content compared to control on Day '20' after BROMO plus PTU treatment can be explained by the unchanged DII activity. Again, an unchanged DII activity compared to control after HALO treatment on Day ' 2 ' could well be the reason for an unperturbed level of synaptosomal T3. Moreover, the lower DII activity in HALO plus PTU-treated rats on Day '20' accounted for the lower synaptosomal T3 content.

Cyclic AMP (cAMP) synthesized by adenylyl cyclase, is an important second messenger in all cells. In astrocytes, cAMP stimulation is required to express DII activity [20]. There has been a significant rise in the cerebrocortical cAMP content on the day of onset of the 'central thyroid hormone homeostasis' (Day '2'), which accounted for the increase in the activity of DII and subsequent rise in brain T3 level [8]. Similarly, the fall in cAMP level on Day ' 20 ' has been accompanied by a corresponding lower cerebral DII activity and T3 content [8]. BROMO and HALO showed opposite levels of cAMP when they were injected either alone, or along with PTU during the days of onset and termination of central homeostasis. BROMO, a $\mathrm{D}_{2}$-receptor agonist, is proposed to couple with $\mathrm{G}_{\alpha \mathrm{i}}$ and inhibit adenylyl cyclase and accumulation of cAMP $[3,21,22]$ and the antagonist is expected to do the reverse. The same phenomenon was observed after treatment with either BROMO or HALO without PTU under normal conditions. But PTU injections in combination with either of the drugs seemed to reverse the receptor-mediated effect on cerebrocortical cAMP content and the effect became much pronounced after long-term PTU treatment. Under such circumstances, $\mathrm{D}_{2}$ receptor-mediated inhibition of adenylyl cyclase was gradually reversed to $\mathrm{D}_{1}$ receptor-mediated activation of adenylyl cyclase activity that increased intracellular cAMP. Studies have also revealed that the efficacy of $B R O M O$ at the $D_{1}$ receptor increased in presence of agents enhancing adenylyl cyclase activity [23]. PTU treatment alone for two days increased cAMP content on Day ' 2 ' [8]. This $\mathrm{D}_{1}$ receptor activation of $\mathrm{BROMO}$ in presence of PTU could account for higher cAMP content in this study. Again, HALO could exhibit antagonistic properties at the $\mathrm{D}_{1}$ receptor and result in lower cAMP content [24]. However, this discrepancy in the cAMP level cannot be totally explained in the light of DII activity and needs further investigation.

The involvement of adrenergic receptors in the maintenance of 'central thyroid hormone homeostasis' has already been established [25]. The present study indicates a possible role of another class of catecholaminergic compounds, the dopamines, in the mediation of 'central thyroid hormone homeostasis'. The antiparkinsonian drug and dopaminergic receptor agonist, bromocryptine (BROMO) can prolong the duration of 'central thyroid hormone homeostasis', while the antagonist haloperidol (HALO) had no significant effect on 'central thyroid hormone homeostasis'. Such effect of bromocryptine might indicate a new role of thyroid hormones in Parkinsonism as some of the depressive and cognitive symptoms typical of hypothyroidism are also features of Parkinsonism.

\section{Grant Support}

Thanks are due to the Council of Scientific and Industrial Research (CSIR), New Delhi, India for providing financial assistance in the form of a Research fellowship to Samita Kundu.

\section{References}

1. Whybrow PC, Prange AJ, Jr. A hypothesis of thyroidcatecholamine-receptor interaction. Its relevance to affective illness. Arch Gen Psychiatry. 1981;38(1):106113.

2. Claustre J, Balende C, Pujol JF. Influence of the thyroid hormone status on tyrosine hydroxylase in central and peripheral catecholaminergic structures. Neurochem Int. 1996;28(3):277-281.

3. Whybrow PC, Prange AJ, Jr., Treadway CR. Mental changes accompanying thyroid gland dysfunction. A reappraisal using objective psychological measurement. Arch Gen Psychiatry. 1969;20(1):48-63.

4. Bauer M, Whybrow PC. Thyroid hormone, brain and behaviour. In: Pfaff D, Arnold A, Etgen A, Fahrbach S, Rubin R, eds. Hormones, Brain and Behaviour. Vol 2. San Diego: Academic Press, 2002: 239-264

5. Baumgartner A, Campos-Barros A, Meinhold H. Thyroid hormones and depressive illness: implications for clinical and basic research. Acta Med Austriaca. 1992;19 Suppl 1:98-102.

6. Kundu S, Pramanik M, Roy S, De J, Biswas A, Ray AK. Maintenance of brain thyroid hormone level during peripheral hypothyroid condition in adult rat. Life Sci. 2006;79(15):1450-1455.

7. Sarkar PK, Ray AK. A simple biochemical approach to 
differentiate synaptosomes and non-synaptic mitochondria from rat brain. Methods Find Exp Clin Pharmacol. 1992;14(7):493-497.

8. Kundu S, Roy S, De J, Biswas A, Pramanik M, Ray AK. Maintenance of homeostasis for thyroid hormone in the adult rat brain: possible involvement of a nuclear-mediated phenomenon. Neuroendocrinology. 2007;86(2):94-103.

9. Ködding R, Fuhrmann H, von zur Muhlen A. Investigations on iodothyronine deiodinase activity in the maturing rat brain. Endocrinology. 1986;118(4):1347-1352.

10. Bradford MM. A rapid and sensitive method for the quantitation of microgram quantities of protein utilizing the principle of protein-dye binding. Anal Biochem. 1976;72:248-254.

11. Devoto P, Flore G, Pani L, Gessa GL. Evidence for corelease of noradrenaline and dopamine from noradrenergic neurons in the cerebral cortex. Mol Psychiatry. 2001;6(6):657-664.

12. Missale C, Nash SR, Robinson SW, Jaber M, Caron MG. Dopamine receptors: from structure to function. Physiol Rev. 1998;78(1):189-225.

13. Montmayeur JP, Guiramand J, Borrelli E. Preferential coupling between dopamine D2 receptors and G-proteins. Mol Endocrinol. 1993;7(2):161-170.

14. Puymirat J, Luo M, Dussault JH. Immunocytochemical localization of thyroid hormone nuclear receptors in cultured hypothalamic dopaminergic neurons. Neuroscience. 1989;30(2):443-449.

15. Vaccari A, Rossetti ZL, de Montis G, Stefanini E, Martino E, Gessa GL. Neonatal hypothyroidism induces striatal dopaminergic dysfunction. Neuroscience. 1990;35(3):699-706.

16. Cooper DS, Kieffer JD, Halpern R, Saxe V, Mover H, Maloof F, Ridgway EC. Propylthiouracil (PTU) pharmacology in the rat. II. Effects of PTU on thyroid function. Endocrinology. 1983;113(3):921-928.
17. Maayan ML, Sellitto RV, Volpert EM. Dopamine and L-dopa: inhibition of thyrotropin-stimulated thyroidal thyroxine release. Endocrinology. 1986;118(2):632-636.

18. Coiro V, Volpi R, Cataldo S, Capretti L, Caffarri G, Pilla $\mathrm{S}$, Chiodera P. Dopaminergic and cholinergic involvement in the inhibitory effect of dexamethasone on the TSH response to TRH. J Investig Med. 2000;48(2):133136.

19. Bianco AC, Salvatore D, Gereben B, Berry MJ, Larsen PR. Biochemistry, cellular and molecular biology, and physiological roles of the iodothyronine selenodeiodinases. Endocr Rev. 2002;23(1):38-89.

20. Safran M, Farwell AP, Leonard JL. Catalytic activity of type II iodothyronine 5'-deiodinase polypeptide is dependent upon a cyclic AMP activation factor. J Biol Chem. 1996;271(27):16363-16368.

21. Enjalbert A, Bockaert J. Pharmacological characterization of the D2 dopamine receptor negatively coupled with adenylate cyclase in rat anterior pituitary. Mol Pharmacol. 1983;23(3):576-584.

22. Onali P, Olianas MC, Gessa GL. Characterization of dopamine receptors mediating inhibition of adenylate cyclase activity in rat striatum. Mol Pharmacol. 1985;28(2):138-145.

23. Perachon S, Schwartz JC, Sokoloff P. Functional potencies of new antiparkinsonian drugs at recombinant human dopamine D1, D2 and D3 receptors. Eur J Pharmacol. 1999;366(2-3):293-300.

24. Cussac D, Pasteau V, Millan MJ. Characterisation of Gs activation by dopamine D1 receptors using an antibody capture assay: antagonist properties of clozapine. Eur J Pharmacol. 2004;485(1-3):111-117.

25. Kundu S, Biswas A, Roy S, De J, Pramanik M, Ray AK. Thyroid hormone homeostasis in brain: possible involvement of adrenergic phenomenon in adult rat. Neuroendocrinology. 2009;89(2):140-151. 